\title{
Pengaruh kondisi parameter pengelasan MAG sambungan las baja tidak sejenis terhadap struktur mikro dan kekerasan daerah HAZ
}

\author{
Harlian Kadir $^{1 *}$, Riswanda1, Abdul Syukur Alfauzi², Bambang Sumiyarso² \\ ${ }^{1}$ Jurusan Teknik Mesin, Politeknik Negeri Bandung, \\ Jl. Gegerkalong Hilir, Ds. Ciwaruga, Kotak Pos 1234, Bandung 4001 \\ ${ }^{2}$ Jurusan Teknik Mesin, Politeknik Negeri Semarang, \\ Jl. Prof Sudarto, SH, Semarang 50275, Indonesia \\ *E-mail: harliankadir@polban.ac.id
}

Diterima: 16-11-2021; Direvisi: 13-12-2021; Dipublikasi: 30-12-2021

\begin{abstract}
Abstrak
Makalah ini difokuskan pada pengaruh kondisi parameter pengelasan MAG (Metal Active Gas) terhadap sifat kekerasan daerah HAZ, dan struktur mikro sambungan las baja tidak sejenis. Dalam industri Fabrikasi dan disain difokuskan pada kebutuhan untuk menggabungkan logam yang tidak sejenis, karena kebutuhan atau prasyarat Teknik baru disain yang kreatif dan sifat rancangan khusus. Baja karbon rendah Hypoeutektoid (AISI 1015) dan baja tahan karat austentik (304L SS) dipilih dalam penelitian ini. Arus las digunakan dengan tiga variasi yang berbeda pada 120A, 130A dan 140A. Pengelasan MAG menggunakan kawat elektroda padat ER70S6, dengan diameter 1,2 mm. Identifikasi struktur makro di daerah terpengaruh panas (HAZ) dan kekerasan mikro vickers dan pengujian tarik dilakukan untuk setiap spesimen hasil las. Struktur makro sambungan las yang berbeda menunjukkan hasil pada variasi arus las 120A, kualitas sambungan las dan penetrasi lebih baik, jika dibandingkan dengan yang menggunakan arus las 130A dan 140A yang memiliki penetrasi berlebihan. Hasil kekerasan mikro vickers pada logam las lebih tinggi jika dibandingkan dengan logam induk dan baja hypoeutektoid (AISI 1015) dan baja tahan karat austenitik AISI 304L, dan kekerasan vickers pada logam las juga lebih tinggi karena pengaruh elektroda kawat padat ER70S6 yang digunakan. Hasil pengujian kekuatan tarik dan kekuatan luluh sambungan las MAG meningkat pada 120A dan 140A, dan patahan terjadi ada pada baja hipo euctektoid (AISI 1015) dibatas antara daerah yang terpengaruh panas dan logam induk. Dari penelitian ini didapatkan bahwa sambungan las MAG dengan arus las 120A lebih baik digunakan untuk penyambungan logam tidak sejenis antara baja karbon rendah (AISI 1015) dan baja tahan karat austenitik (AISI 304L).
\end{abstract}

Kata kunci: AISI 1015; ASS 304L; Hypo Eutektoid, HAZ ; MAG.

\begin{abstract}
This paper focuses on the effect of MAG (Metal Active Gas) welding parameter conditions on the hardness at HAZ and micro structure of dissimilar steel welded joints. The fabrication and design industry is focuses with the need to combine dissimilar metals, because of the need or prerequisite for new creative design techniques and special design properties. Hypoeutectoid low carbon steel (AISI 1015) and austenitic stainless steel (304L SS) were selected in this study. Welding current is used with three different variations at 120A, 130A and 140A. MAG welding uses ER70S6 solid electrode wire, with a diameter of $1.2 \mathrm{~mm}$. Identification of the macrostructure in the heat affected area (HAZ) and micro vickers hardness and tensile testing was carried out for each weld specimen. The macro structure of different welded joints shows that the welding current varies from 120A, the quality of the welded connection and penetration is better, when compared to those using 130A and 140A welding currents which have excessive penetration. The micro vickers hardness of the weld metal is higher than that of the base metal and hypoeutectoid steel (AISI 1015) and austenitic stainless steel AISI 304L, and the vickers hardness of the weld metal is also higher due to the influence of the solid wire electrode ER70S6 used. The results showed that the tensile strength and yield strength of MAG welded joints increased at 120A and 140A, and fracture occurred in the hypo-euctectoid steel (AISI 1015) at the boundary between the heat-affected region and the base metal. From this study it was found that MAG welding joints with welding currents of 120A are better used for joining dissimilar metals between low carbon steel (AISI 1015) and austenitic stainless steel (AISI 304L
\end{abstract}

Keywords : AISI 1015; ASS 304L; Hypo Eutektoid, HAZ; MAG

\section{Pendahuluan}

Pengelasan material tidak sejenis selalu dilakukan dalam menanggapi kebutuhan atau permintaan tertentu dari industri. Beberapa komponen elektronik, di bidang minyak dan gas bumi, aeronautika dan otomotif, komponen dibuat 
Kadir dkk. /Jurnal Rekayasa Mesin p-ISSN: 1411-6863, e-ISSN: 2540-7678 Vol.16|No.3|457-466|Desember|2021

dengan sambungan las logam tidak sejenis secara bersama-sama untuk meningkatkan sifat mekanik dan fungsinya. Permintaan untuk pengelasan yang berbeda dari logam tersebut meningkat karena peluang yang ditawarkannya. Misalnya, sifat unik dari logam yang berbeda digunakan sehingga menghasilkan komponen yang unggul dan properti yang disesuaikan dengan biaya minimal. Baja tahan karat, terutama jenis austenitik (misalnya AISI 304L), memberikan hasil yang sangat baik ketahanan korosi dan kekuatan tarik tinggi tetapi merupakan bahan yang relatif mahal $[1,2]$. Sedangkan baja karbon rendah adalah lebih murah, tersedia dan memberikan kekuatan benturan tinggi. Akibatnya, Metal Active Gas welding (MAG) digunakan untuk pengelasan logam yang tidak sejenis, seperti baja tahan karat austenitik AISI 304 dan baja karbon rendah di industri minyak dan gas yang semakin banyak digunakan karena ada beragam kondisi lingkungan yang terkait dengan industri ini yang dapat mempengaruhi kegagalan fungsi dari komponen baja yang dipasang sebagai utilitas dan struktur.

Salah satu jenis pengelasan yang banyak di pakai untuk mengelasan baja karbon dan baja tahan karat austenitik adalah Metal Active Gas Welding yang merupakan bagian dari Gas Metal Arc Welding (GMAW) yang menggunakan gas pelindung (inert gas) karbon dioksida (CO2) dan secara prinsip dan peralatan las nya sama. Pengelasan MAG menggunakan kawat las sekaligus elektroda, yang berupa gulungan kawat (rol) ER\&70S6 dengan diameter $1.2 \mathrm{~mm}$ dan gerakannya di atur oleh motor listrik [3, 4]. Penyambungan logam-logam yang memiliki perbedaan temparatur titik cair atau konduktivitas panas juga sulit karena logam yang satu akan mencair, sementara yang lain belum. Penelitian mengenai sifat mekanik dan struktur mikro atau aspek metallurgi dari jenis sambungan ini sangat penting dalam prasyarat disain dan sudut pandang analisis keselamatan [5]. Sifat kelarutan antara logam yang berbeda untuk menjadi satu yaitu paduan adalah persyarat utama untuk mendapatkan ikatan metalurgi dari paduan tersebut. Atau, logam tambah (logam pengisi) atau filler metal, yang larut dengan masing-masing logam tidak sejenis yang akan disambung, diperlukan untuk menghasilkan logam las. Jika koefisien muai panas kedua logam yang akan disambung sangat berbeda, maka sambungan mungkin gagal karena kelelahan termal [6].

Baja tahan karat austenitik tipe 304L adalah material logam yang serba guna yang sifat tekniknya telah diakui dengan baik di berbagai aplikasi pengelasan logam. 304L adalah baja tahan karat austenitik yang paling bisa di las dari semua seri 304. Las fusi adalah proses yang umum untuk penyambungan komponen fabrikasi baja termasuk Dissimilar Metal Welding (DMW) dari baja tahan karat austenitik dan baja ferritik. Parameter pengelasan (seperti: tegangan, arus las kecepatan pengelasan, filler metal, komposisi gas pelindung, besaran tekanan gas pelindung dan metoda pengelasan, sangat penting untuk menghasilkan kualitas hasil las yang dipengaruhi oleh sifat mekanik dan struktur mikro [7, 8]. Dalam penelitian ini pengaruh parameter pengelasan MAG sambungan las baja tidak sejenis terhadap struktur mikro dan kekerasan pada daerah terpengaruh panas (HAZ) baja karbon rendah (AISI 1015) dan baja tahan karat austenitik ( AISI 304L), dengan memvariasikan arus las yang digunakan. Tujuan penelitian ini adalah analisa pengaruh kondisi parameter pengelasan MAG (Metal Active Gas) terhadap sifat kekerasan daerah HAZ, dan struktur mikro sambungan las baja tidak sejenis.

\section{Material dan metodologi}

\subsection{Benda kerja las}

Material yang digunakan yaitu pelat baja hypo-eutektoid atau baja karbon rendah (AISI 1015) dengan baja tahan karat austenitik (AISI 304L) dengan tebal $3 \mathrm{~mm}$, dan dilakukan pengujian komposisi kimia untuk masing masing logam induk yang menjadi sampel benda kerja las, dengan data hasil pengujian pada Tabel 1 berikut ini. 
Kadir dkk. /Jurnal Rekayasa Mesin p-ISSN: 1411-6863, e-ISSN: 2540-7678

Vol.16|No.3|457-466|Desember|2021

Tabel 1. Komposisi kimia logam induk dan elektroda kawat elektroda

\begin{tabular}{ccccccccccc}
\hline \multirow{2}{*}{ Material/Wire } & \multicolumn{10}{c}{ Presentase (\%) } \\
\cline { 2 - 11 } & $\mathrm{C}$ & $\mathrm{Cr}$ & $\mathrm{Ni}$ & $\mathrm{Mn}$ & $\mathrm{Si}$ & $\mathrm{P}$ & $\mathrm{S}$ & $\mathrm{Mo}$ & $\mathrm{Cu}$ & $\mathrm{Fe}$ \\
\hline ASS 304L & 0,028 & 18,24 & 8,04 & 1,469 & 0,42 & 0,028 & 0,004 & - & 0,031 & 71,6 \\
\hline AISI 1015 & 0,142 & 0,02 & 0,05 & 0,454 & 0,132 & 0,015 & 0,012 & 0,016 & 0,007 & 99,109 \\
\hline ER 70S-6 & $0,07-0,015$ & 0,15 & 0,15 & $1,40-1,85$ & $0,80-1,15$ & 0,025 & 0,035 & - & 0,5 & - \\
\hline
\end{tabular}

\subsection{Proses pengelasan}

Proses pengelasan dilakukan secara manual dengan moda perpindahan logam cair (metal transfer droplet) short circuit, dengan polaritas Direct Current Reverse Polarity (DCRP). menggunakan logam tambah (filler metal) ER 70S6, dengan diameter $1.2 \mathrm{~mm}$, dengan menggunakan gas pelindung (inert gas) karbon dioksida (CO2). Posisi datar (PA) digunakan dalam pengelasan ini dan benda kerja di klem menggunakan alat bantu las. Sambungan las menggunakan sambungan tumpul (butt joint) dengan sudut bevel $60^{\circ}$. Pengelasan dilakukan single pass dengan moda stringer bead untuk masing masing arus las yang digunakan yaitu 120A, 130A dan 140A, dengan tegangan (voltase) dan kecepatan kawat yang konstan, seperti ditunjukkan pada Tabel 2 berikut ini.

Tabel 2. Parameter pengelasan MAG

\begin{tabular}{clcc}
\hline No. & \multicolumn{1}{c}{ Parameter pengelasan } & Sampel 1 & Sampel 2 \\
\hline 1. & Arus $(\mathrm{A})$ & 120 & 130 \\
\hline 2. & Voltase $(\mathrm{V})$ & 20 \\
\hline 3. & Travel speed $(\mathrm{mm} / \mathrm{s})$ & 3,5 \\
\hline 4. & Dimensi $(\mathrm{mm})$ & $300 \times 125 \times 3$ \\
\hline 5. & Posisi pengelasan & $1 \mathrm{G} / \mathrm{PA}$ \\
\hline 6. & Tekanan gas pelindung $(\mathrm{L} / \mathrm{min})$ & 15 \\
\hline 7. & Gas pelindung & $\mathrm{CO}_{2}$ \\
\hline 8. & Polaritas arus las & DCRP \\
\hline 9. & Kawat elektroda & ER70S-6 (Ø 1,2 $\mathrm{mm})$ \\
\hline
\end{tabular}
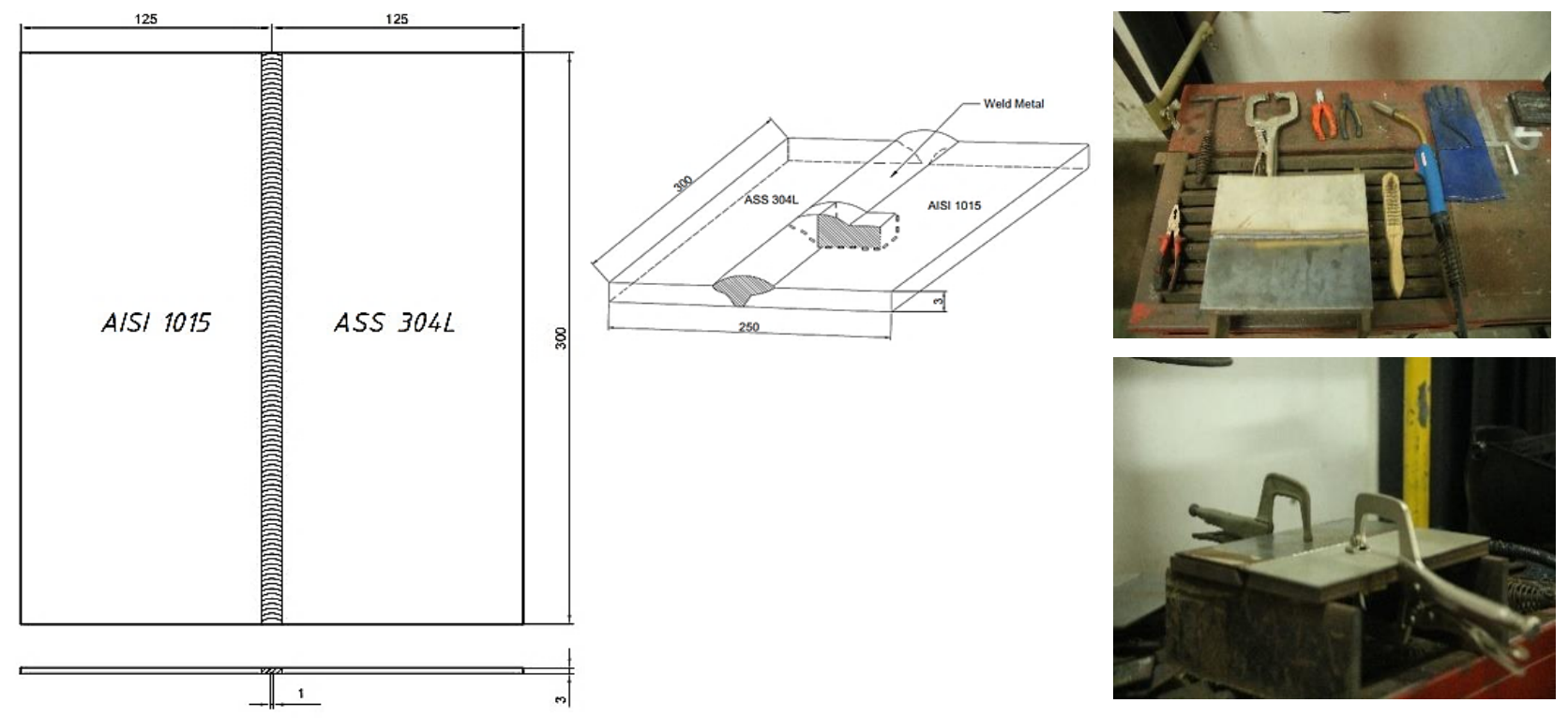

Gambar 1. Benda kerja las baja tidak sejenis 
Kadir dkk. /Jurnal Rekayasa Mesin

p-ISSN: 1411-6863, e-ISSN: 2540-7678

Vol.16|No.3|457-466|Desember|2021

\subsection{Pembuatan spesimen uji}

Sampel pelat baja karbon rendah (AISI 1015) dan baja tahan karat austenitik (AISI 3041) hasil pengelasan MAG di potong menjadi beberapa bagian dan dilakukan preparasi sesuai prosedur dan standar sebelum digunakan untuk pengujian kekerasan dan pemeriksaan struktur mikro, sambungan logam las tidak sejenis (dissimilar metal weld joint).

\subsection{Pengujian kekerasan}

Pengujian kekerasan dilakukan dengan cara penekanan menggunakan indentor, dan pengujian kekerasan mikro vickers yang dipilih untuk digunakan. Pengujian kekerasan mikro vickers dilakukan dengan menggunakan alat yang secara otomatis terhubung dengan perangkat lunak (software) dan terkoneksi dengan alat melalui analisa gambar material yang diuji. Metoda kekerasan mikro vickers (micro hardness vickers) dilakukan dalam proses pengujian kekerasan hasil las. Jarak antara titik uji adalah $300 \mu \mathrm{m}$ dan beban $200 \mathrm{gf}$ serta waktu penahanan beban selama 10 detik dan titik-titik pengujian ditunjukkan pada Gambar 2.

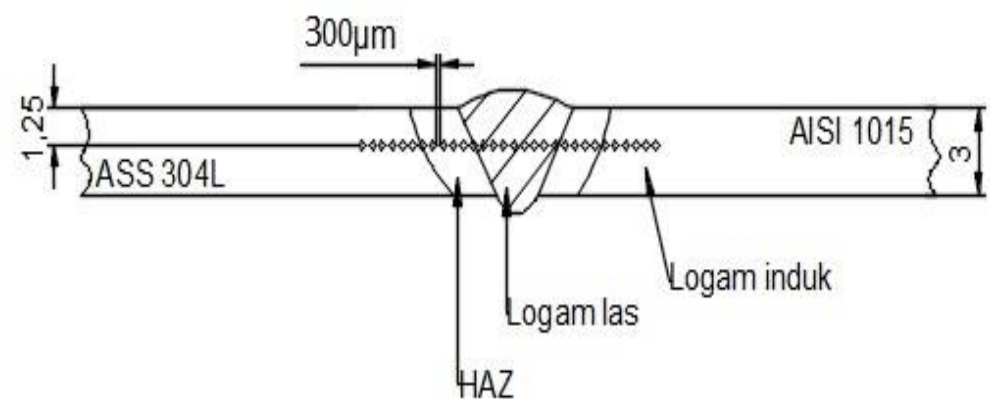

Gambar 2. Posisi pengujian kekerasan mikro Vickers

Rumus yang digunakan untuk mendapatkan nilai kekerasannya adalah:

$D=\frac{d_{1}+d_{2}}{2}$

$V H N=\frac{2 P \sin \left(\frac{\theta}{2}\right)}{D^{2}}$

$V H N=1.854 \frac{P}{D^{2}}$

Dimana:

$V H N=$ Nilai kekerasan vikers

$D \quad=$ Diagonal rata-rata bekas indentor $(\mathrm{mm})$

$d_{1} \quad=$ Diagonal 1 bekas indentor $(\mathrm{mm})$

$d_{2} \quad=$ Diagonal 1 bekas indentor $(\mathrm{mm})$

$P \quad=$ Berat pembebanan $(\mathrm{Kgf})$

$\theta \quad=$ besar sudut permukaan intan $136^{\circ}$

\subsection{Pembuatan sampel struktur mikro}

Pemeriksaan struktur mikro sambungan las baja tidak sejenis dilakukan dengan terlebih dahulu melakukan preparasi sampel specimen yang akan di periksa, seperti ditunjukkan pada Gambar 3 berikut ini. 
Kadir dkk. /Jurnal Rekayasa Mesin p-ISSN: 1411-6863, e-ISSN: 2540-7678

Vol.16|No.3|457-466|Desember|2021
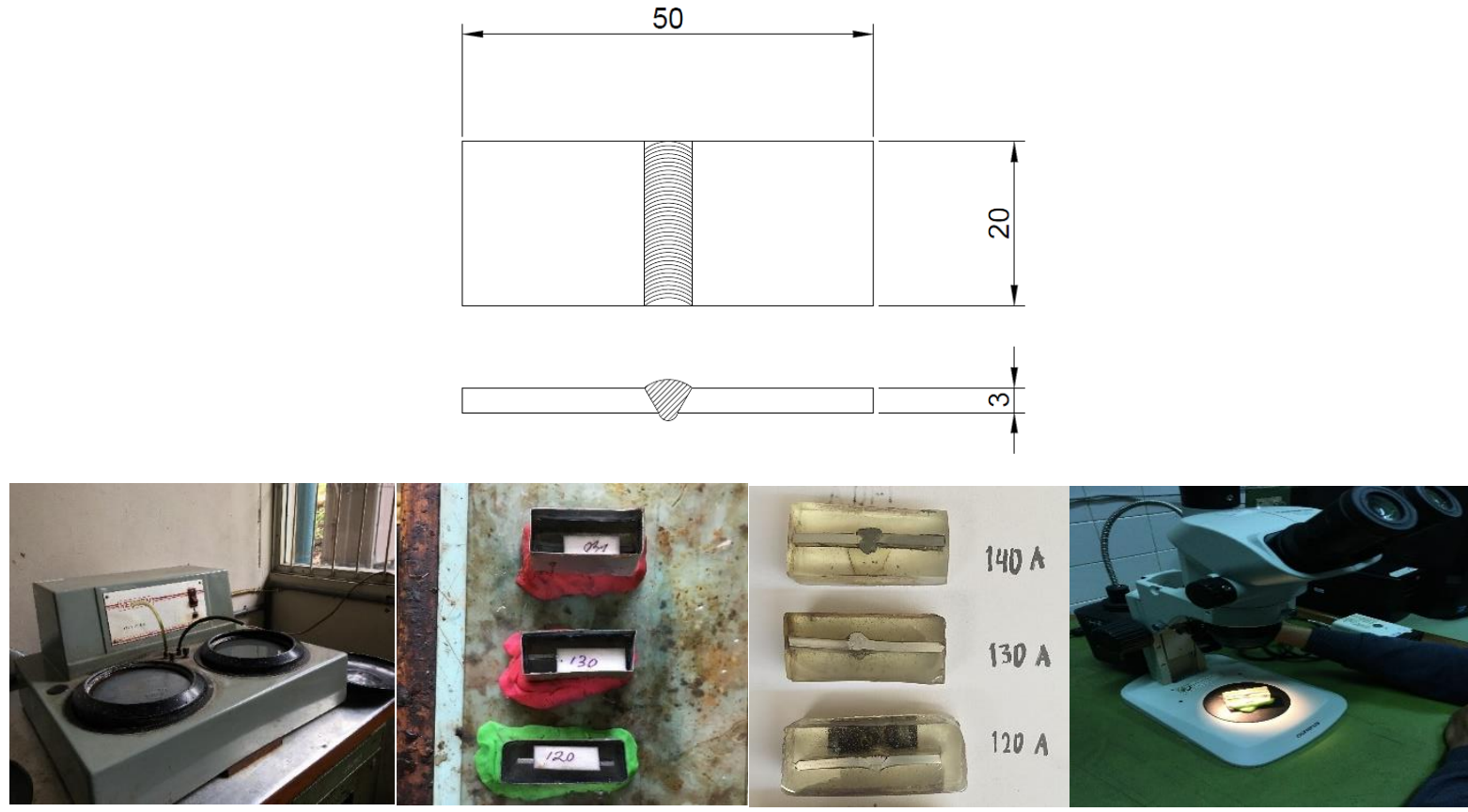

Gambar 3. Pembuatan sampel struktur mikro

\section{Hasil dan pembahasan}

\subsection{Pemeriksaan secara visual}

Hasil pengelasan yang menggunakan arus las 120A, secara visual penetrasi hasil las (root pass) tidak tembus dan di beberapa bagian terdapat kampuh las yang tidak sama lebarnya. Sedangkan hasil pengelasan yang menggunakan arus las 130A hasil penetrasi lasan sudah menghasilkan tembusan yang jauh lebih baik, bila dibandingkan dengan penggunaan arus las 120A, dan untuk penggunaan arus las 140A hasil penetrasi lasan sudah lebih baik dan secara visual dapat dilihat kampuh las yang dihasilkan lebih lebar bila dibandingkan dengan hasil lasan pada arus las 120A dan 130A. Proses pengelasan dilakukan secara manual dengan parameter las yang dibuat konstan, seperti : tegangan (voltage), tekanan gas pelindung, kecepatan pengelasan, dan polaritas yang digunakan.

Tabel 3. Root dan Face hasil las baja tidak sejenis

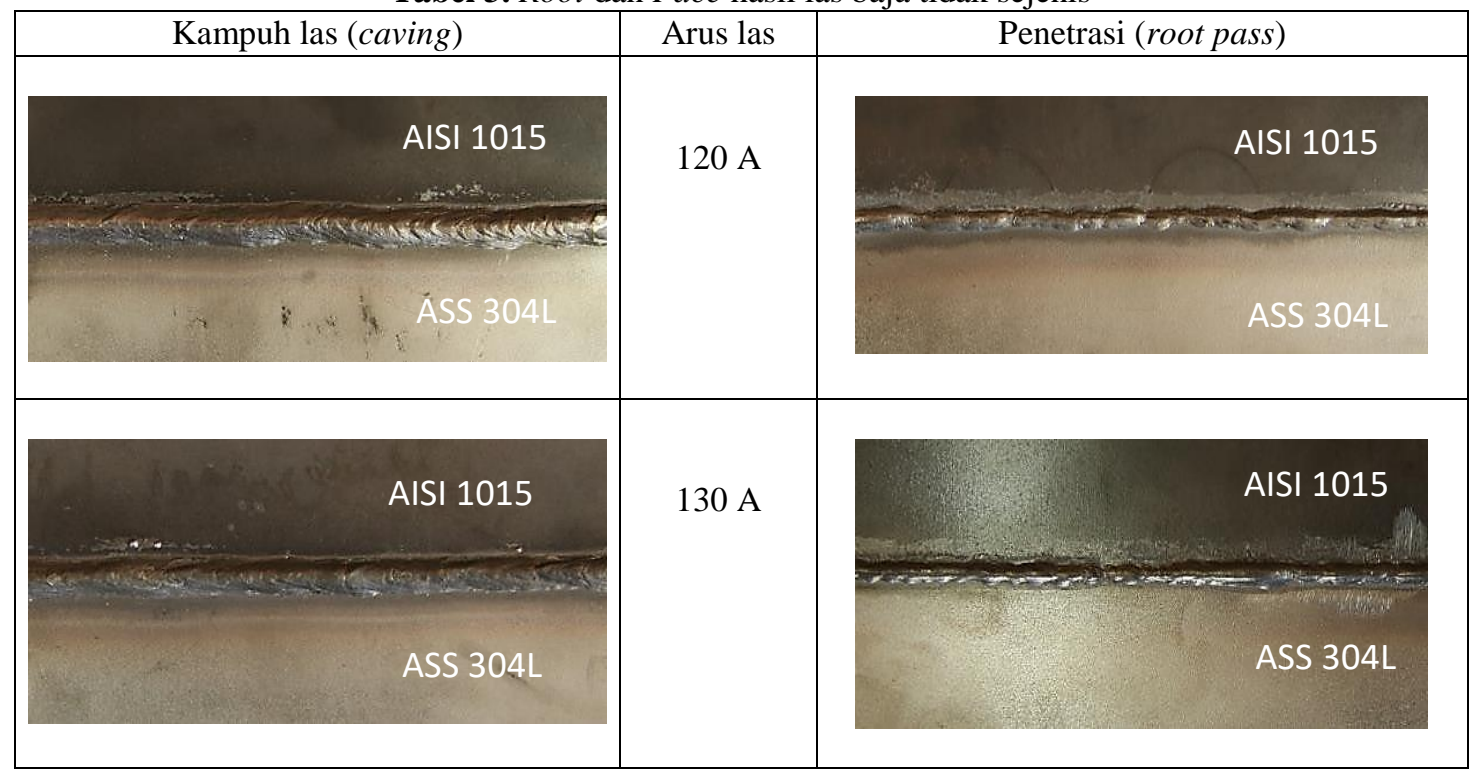


Kadir dkk. /Jurnal Rekayasa Mesin

p-ISSN: 1411-6863, e-ISSN: 2540-7678

Vol.16|No.3|457-466|Desember|2021
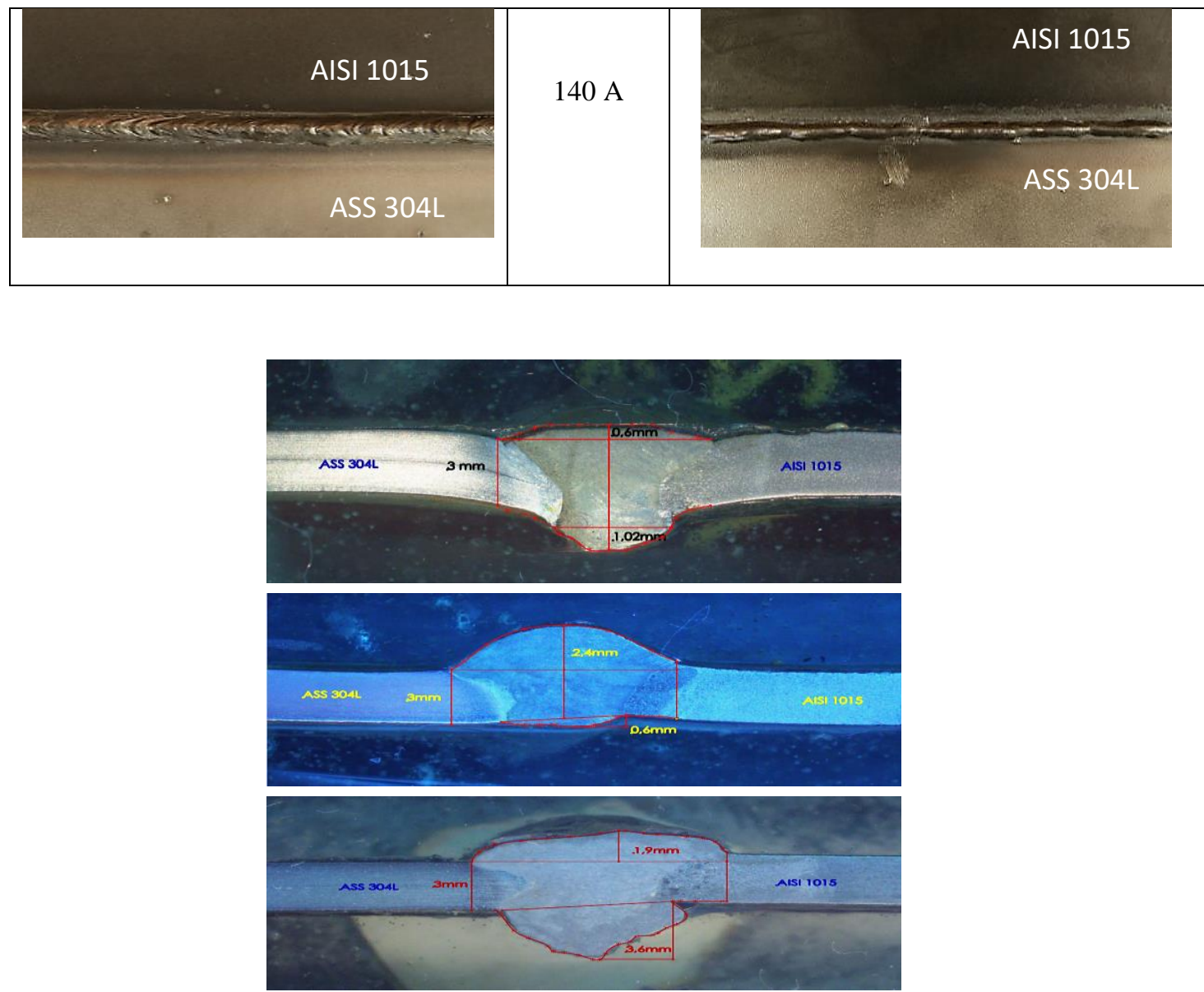

Gambar 4. Struktur makro hasil las baja tidak sejenis

Penetrasi hasil las untuk penggunaan arus las 120A dan 140A penetrasi berlebih (excessive penetration) dan terjadi perubahan bentuk atau deformasi dari dua pelat logam baja tidak sejenis yang di sambung. Sedangkan untuk penggunaan arus las 130 A jauh lebih baik, walaupun terjadi lekukan (distorsi) di bagian bawah sebelah kanan root pass.

\subsection{Pembahasan hasil pengujian kekerasan}

Pengujian ini dilakukan bertujuan untuk mengetahui dan menentukan nilai kekerasan pada hasil lasan terdiri dari daerah terpengaruh panas (HAZ), logam las (weld metal), Daerah batas fusi (fusion line) dan logam induk (parent metal). Jarak titik masing-masing $300 \mu \mathrm{m}$ dengan beban 200 gf. Hasil pengujian diambil dari pusat logam las menuju ke logam induk. Pengambilan data diambil dari dua sisi mengingat material yang digunakan berbeda jenis (AISI 1015 dan ASS 304L) agar dapat membandingkan distribusi kekerasan dari masing-masing material.

Analisa hasil pengelasan MAG dengan menggunakan arus las 120A, nilai kekerasan pada daerah logam induk (parent metal) baja tahan karat 304L mengalami kenaikan ketika mendekati daerah terpengaruh panas (HAZ), yaitu dari 209.90 HV naik menjadi 226.73 HV. Kemudian nilai kekerasan terus naik Ketika memasuki daerah HAZ pada baja tahan karat austenitic (304L SS) menjadi 272.77 HV. Pada daerah logam las (weld metal) nilai kekerasan cenderung stabil dengan nilai kekerasan tertinggi sebesar 318.23 HV. Memasuki daerah terpengaruh panas (HAZ) pada baja karbon rendah (AISI 1015) nilai kekerasan turun secara drastis hingga $180.81 \mathrm{HV}$, dan berlanjut pada daerah logam induk (parent metal) baja karbon rendah, nilai kekerasan turun dengan selisih yang tidak terlalu jauh menjadi $171.71 \mathrm{HV}$. 
Kadir dkk. /Jurnal Rekayasa Mesin p-ISSN: 1411-6863, e-ISSN: 2540-7678

Vol.16|No.3|457-466|Desember|2021

Untuk identifikasi hasil las dengan menggunakan arus las 130A, nilai kekerasan pada daerah logam induk (parent metal) baja tahan karat austenitic 304L SS juga mengalami kenaikan Ketika mendekati daerah terpengaruh panas (HAZ) yaitu 249.06 HV menjadi $259.85 \mathrm{HV}$, dan kemudian nilai kekerasan naik ketika memasuki daerah terpengaruh panas baja tahan karat austenitik menjadi $272.77 \mathrm{HV}$. Pada daerah logam las (weld metal) nilai kekerasan cenderung stabil yaitu 364.15HV, dan ketika memasuki daerah terpengaruh panas (HAZ) baja karbon rendah, nilai kekerasannya menjadi 190.06 HV, dan memasuki daerah logam induk baja karbon rendah turun menjadi 167.11 HV.

Selanjutnya untuk identifikasi pengelasan baja tidak sejenis yang menggunakan arus las 140A, juga mengalami pola yang sama dengan arus las 120A dan 130A, ketika posisi berada pada baja tahan karat austenitik 304L SS nilai kekerasan juga mengalami kenaikan berawal dari $225.62 \mathrm{HV}$ naik menjadi $227.07 \mathrm{HV}$. dan berlanjut ketika memasuki daerah terpengaruh panas naik menjadi 321.61 HV. Pada daerah logam las nilai kekerasan tertinggi yaitu $364.15 \mathrm{HV}$, dan pada waktu memasuki daerah terpengaruh panas baja karbon rendah (AISI 1015) turun secara signifikan menjadi 205 HV, dan berlanjut turun hingga ke daerah logam induk menjadi $196.05 \mathrm{HV}$.

Distribusi kekerasan secara umum membentuk pola grafik yaitu nilai kekerasan pada logam las cenderung lebih tinggi bila dibandingkan dengan daerah terpengaruh panas (HAZ) dan logam induk. Nilai kekerasan terendah terdapat di semua variasi arus las yang digunakan dan terjadi pada daerah baja karbon rendah (AISI 1015).

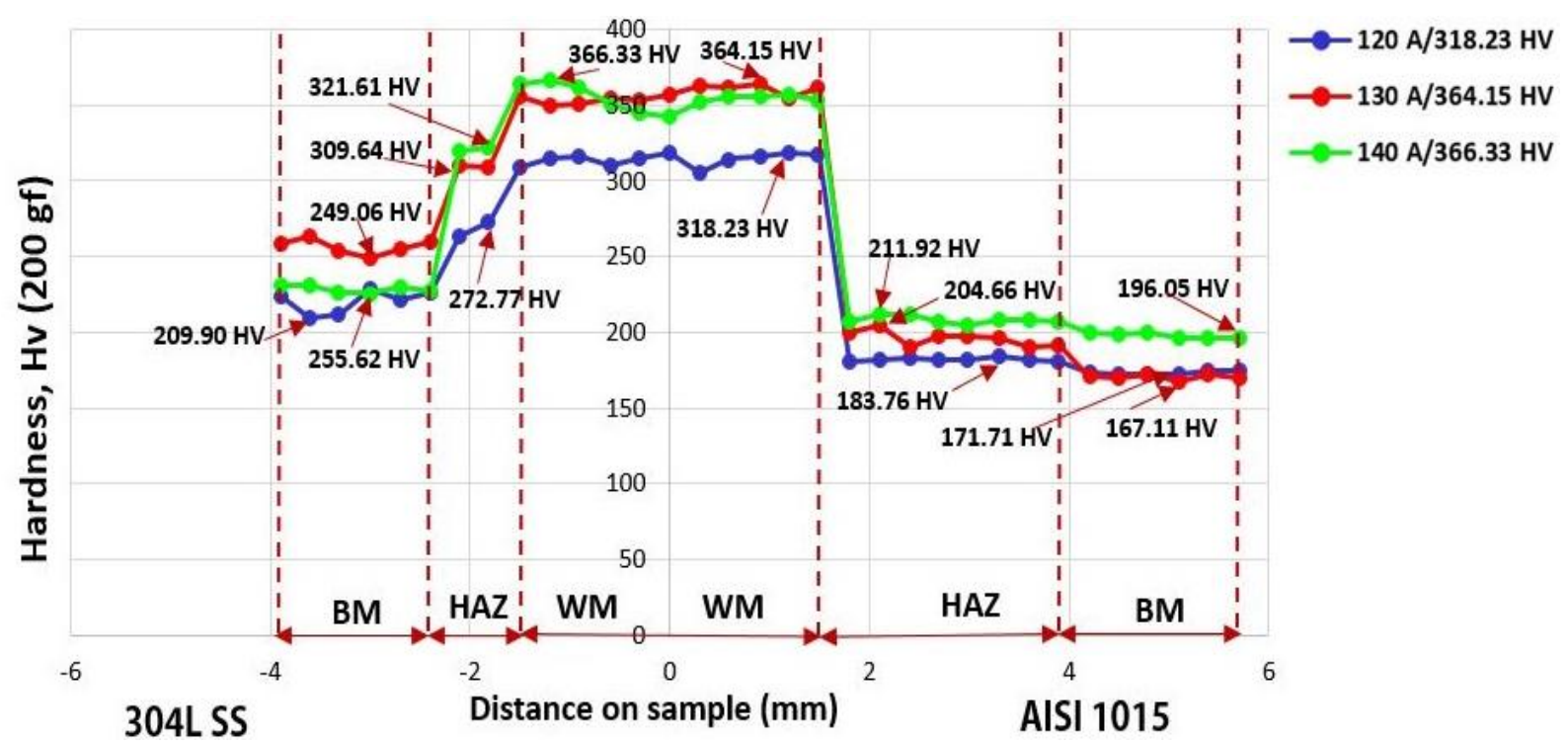

Gambar 5. Grafik nilai kekerasan mikro Vickers

\subsection{Pemeriksaan struktur mikro}

Identifikasi struktur mikro dari specimen pada penggunaan arus las 120 A, $130 \mathrm{~A}$, dan 140 A bertujuan untuk mengidentifikasi struktur mikro yang terbentuk hasil proses pengelasan pada logam las, daerah terpengaruh panas (HAZ),serta logam induk. Pengamatan dilakukan secara visual menggunakan bantuan mikroskop optik dengan mengambil gambar dengan pembesaran 5 sampai dengan 100x. Struktur mikro baja tahan karat austenitik (304L SS) pada logam induk mempunyai fasa dominan (matrik) adalah fasa austenite ( ${ }_{y}$ ) yang bersifat ulet, dengan sel satuan FCC (Face Centered Cubic) dan bersifat tidak dapat dimagnetkan (non magnetic). Sedangkan struktur mikro baja karbon rendah (AISI 1015) mempunyai fasa dominan (matrik) adalah ferrit ( $\alpha$ ) yang bersifat lunak, dengan sel satuan BCC (Body Centered Cubic) dan dapat di magnetkan. Seiring dengan bertambahnya unsur karbon maka pembentukkan fasa pearlite $(\alpha+\mathrm{Fe} 3 \mathrm{C})$ akan semakin banyak, dan akan banyak berpengaruh pada pembentukkan sifat kekerasan yang akan meningkat. Kecendrungan dengan penggunaan 
Kadir dkk. /Jurnal Rekayasa Mesin p-ISSN: 1411-6863, e-ISSN: 2540-7678

Vol.16|No.3|457-466|Desember|2021

kawat elektroda ER 70S 6,yang komposisi kimianya memiliki unsur karbon yang lebih tinggi dari ke dua logam induk yang menjadi benda kerja las. Maka asumsi nilai kekerasan yang terjadi relative lebih tinggi serta struktur mikro logam las yang lebih halus, maka merupakan penyebab naiknya nilai kekerasan di daerah terpengaruh panas dan logam las. Disamping itu hubungan antara laju pendinginan (cooling rate) dan waktu yang terjadi pada saat pembekuan logam las maka cukup mempunyai peran dengan meningkatnya nilai kekerasan di daerah terpengaruh panas (HAZ) dan logam las.

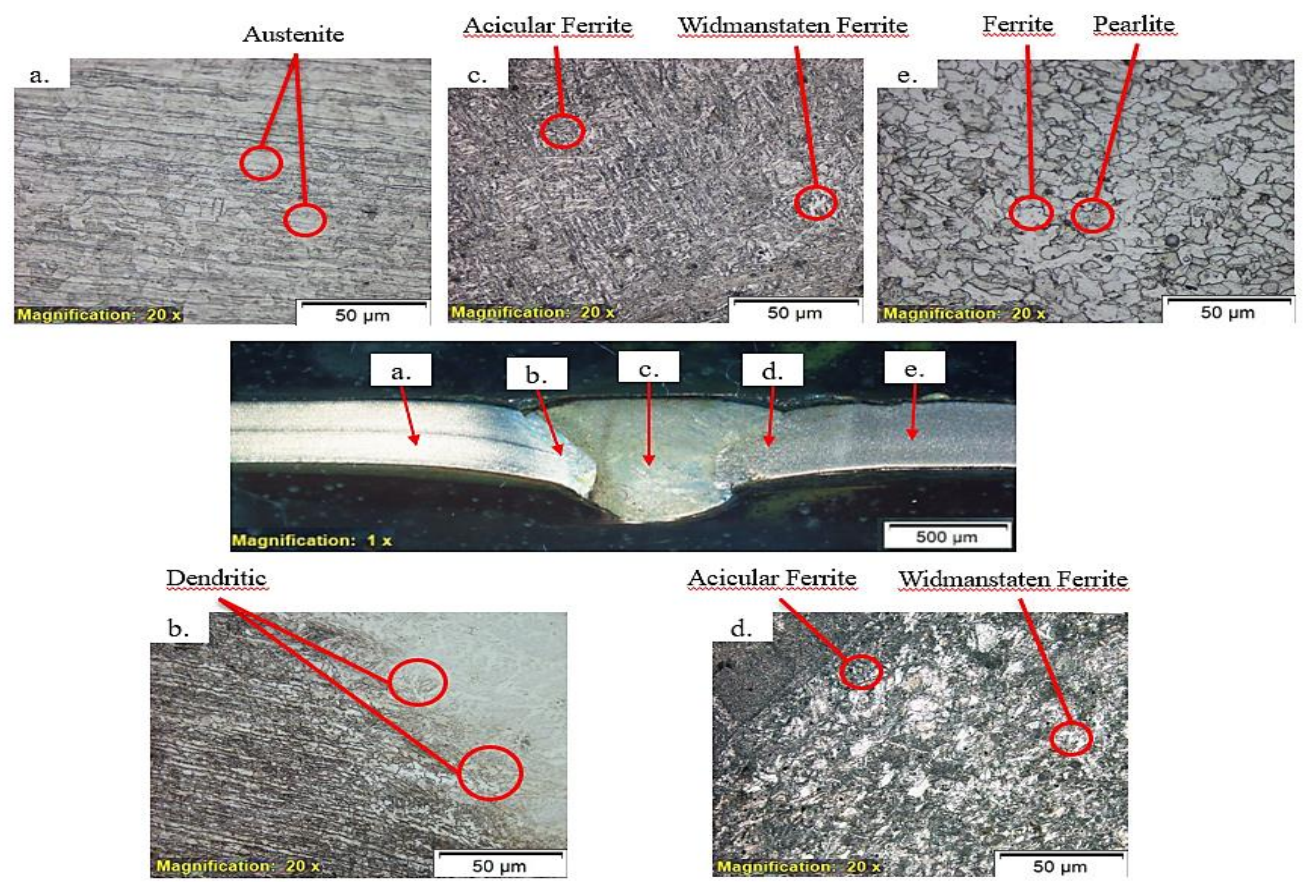

Gambar 6. Struktur mikro baja tidak sejenis pada arus las 120A
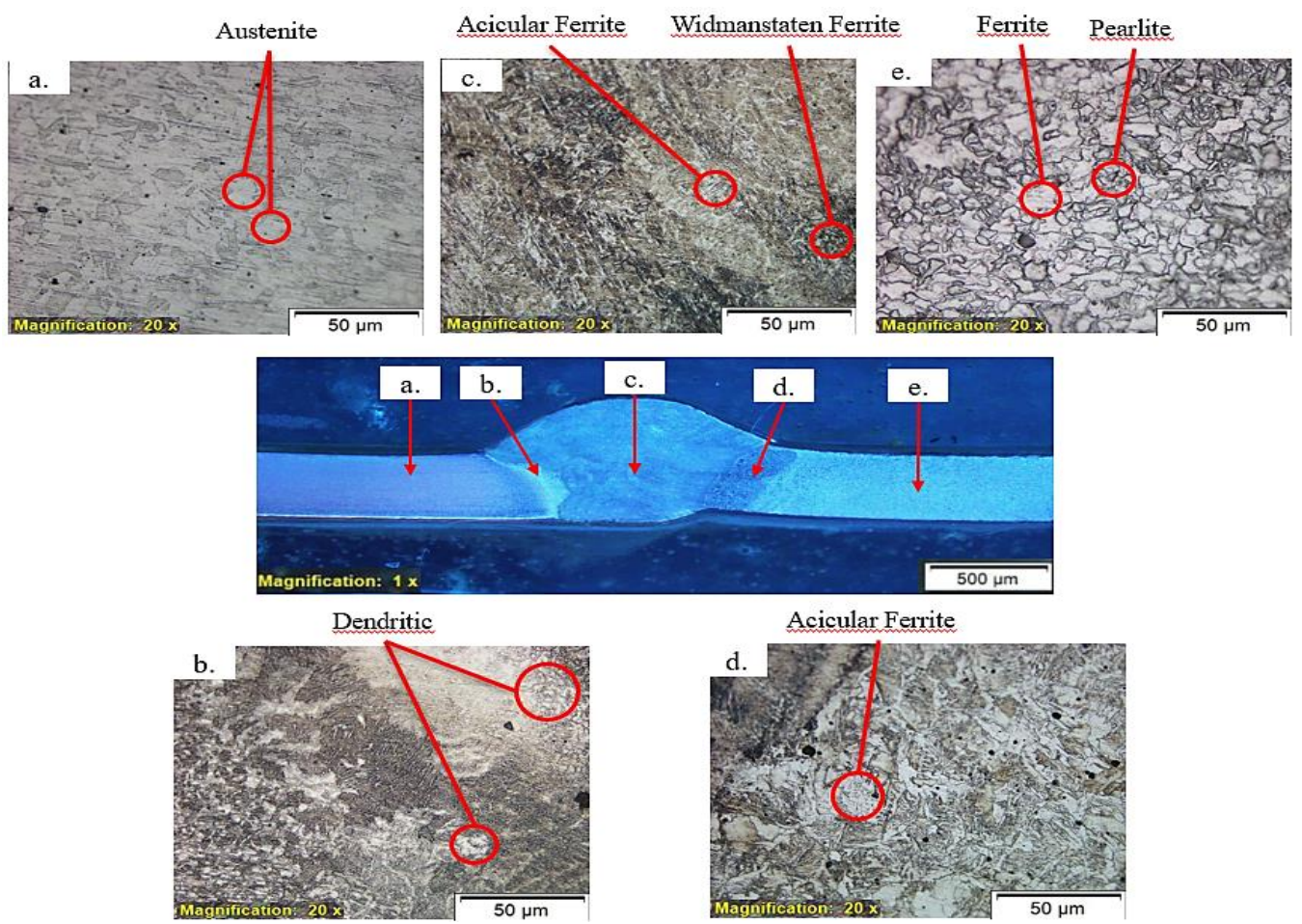

Gambar 7. Struktur mikro baja tidak sejenis pada arus las 130A 
Kadir dkk. /Jurnal Rekayasa Mesin p-ISSN: 1411-6863, e-ISSN: 2540-7678

Vol.16|No.3|457-466|Desember|2021

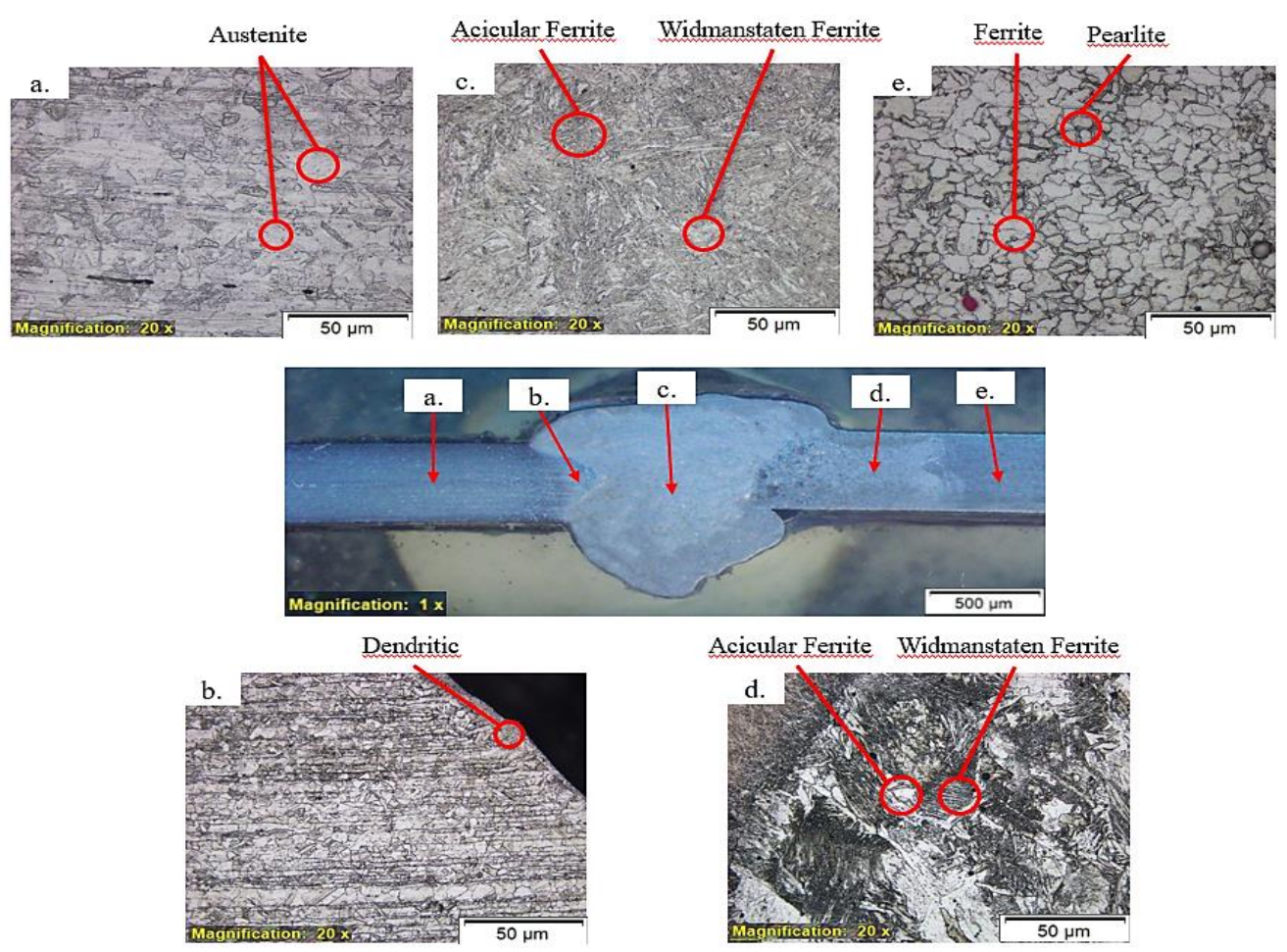

Gambar 8. Struktur mikro baja tidak sejenis pada arus las 140A

Perubahan panas yang disebabkan oleh karakteristik busur las busur listrik oleh pemanasan dan pendinginan dengan yang kecepatan tinggi dan gradien suhu tergantung pada jarak dari las. Perubahan temperatur dari satu titik pada sambungan las sangat bergantung pada karakteristik perubahan panas dan waktu pengelasan [9]. Umumnya, fasa tersusun sebagian besar dari fasa austenit dan fasa ferrit. Dan juga adakalanya terjadi pembentukan dan presipitasi karbida krom karena peristiwa sensitisasi dapat diamati pada batas butir. setelah proses etsa fasa ferrit diperoleh sebagai fasa yang lebih terang diantara fasa austenit yang lebih gelap dan hanya sedikit perbedaan dari hasil observasi struktur mikro logam induk dan daerah terpengaruh panas (HAZ) dari variasi arus las, kecepatan pengelasan yang digunakan [7]. Secara umum struktur mikro logam induk baja tahan karat austenitik (304L SS) dengan matrik dominan fasa austenite dan untuk logam induk baja karbon rendah (AISI 1015) dengan matrik fasa dominan adalah ferrit, sedangkan pada daerah terpengaruh panas dan logam las terdapat fasa dendritik, Acicular ferrite dan Widmanstaten ferrite.

\section{Kesimpulan}

Dari pengujian kekerasan dan pemeriksaan struktur mikro, pengelasan baja tidak sejenis antara baja tahan karat austenitic (304L SS) dan baja karbon rendah (AISI 1015) dapat di tarik kesimpulan bahwa pengelasan baja tidak sejenis antara baja tahan karat austenitik (304L SS) dan baja karbon rendah (AISI 1015) menggunakan las MAG berhasil dengan baik. Nilai kekerasan tertinggi pada penggunaan arus las 120A dan terjadi pada logam las dengan nilai $366.33 \mathrm{HV}$, dan nilai kekerasan terendah berada pada logam induk baja karbon rendah (AISI 1015) dengan nilai kekerasan $167.11 \mathrm{HV}$. Terdapat fasa austenit dominan pada baja tahan karat austenitik dan fasa ferrit dominan pada baja karbon rendah, sedangkan pada daerah terpengaruh panas (HAZ) dan logam las terdapat fasa dendritic, acicular ferrite dan fasa pearlit. Identifikasi secara visual luas daerah terpengaruh panas pada baja karbon rendah lebih besar bila dibandingkan dengan luas daerah terpengaruh panas baja tahan karat austentik (304L SS). 
Kadir dkk. /Jurnal Rekayasa Mesin p-ISSN: 1411-6863, e-ISSN: 2540-7678

Vol.16|No.3|457-466|Desember|2021

\section{Daftar Pustaka}

[1] Jai Paul Dudeja.,Analysis and advantages of Welding Dissimilar Metal by Fiber Laser. International Journal of advanced Scientific Technologies in Engineering and Management Sciences (IJASTERMS -ISSN; 2454-356X), Volume 5,Issue - 8, August 2018.

[2] L.O.Osaba, I.C. Ekpe \& R.A.Elemuren, Analysis Of Dissimilar Welding Of Austenitic Stainless Steel to Low carbon Steel by TIG Welding Process., International Journal of Metallurgical \& Materials Science and Engineering (IJMMSE) ISSN(P) : 2278-2516 ; ISSN (E): 2278 -2574., Vol.5, Issue 5, Oct 2015, 1 -12

[3] T.E.Abioye.,O.E. Ariwoola.,T.I. Ogedengbe.,P.K. Farayibi., O.O.Gbadeyan, Effect of Welding Speed on the Microstructure and Corrosion Behavior of Dissimilar Gas Metal Arc Weld Joints of AISI 304 Stainless Steel and Low Carbon Steel, International Conference on Recent Advanced in Materials, Minerals \& Enviroment (RAMM), Proceedings 17 (2019) $871-877$

[4] Bambang Teguh Baroto., Petrus Heru Sudargo., Pengaruh Arus Listrik dan FILLER Pengelasan Logam Berbeda Baja Karbon Rendah (ST 37) dengan Baja Tahan Karat (AISI 316L) Terhadap Sifat Mekanis dan Struktur Mikro., Prosiding SNATIF ke -4 Tahun 2017, ISBN 978 -602 - 1180.,50-1

[5] M.F.Mamat.,E.Hamzah.,Z.,Ibrahim.,Rohah.A.M.,A.Bahador., Effect of Filler Metals on the Microstructures and Mechanical Properties of Dissimilar Low Carbon Steel and 316L Stainless Steel Welded Joints., Materials Science Forum, Vol 819 (2015) pp 57 -62

[6] M.Velu, Sunil Bhat, Metallurgical and Mechanical examinations of steel - copper joints arc welding using bronze and nickel base superalloy filler materials, Materials and Design 47 (2013) 793 -809

[7] Oyetunji, A., Influence Of Welding variables on the Microstructural and Tensile Properties of 304L Austenitic Stainless Steel Heat Affected Zone., Kathmandu University, Journal of Science Engineering and Technology (JSET), vol.11, No.1, August, 2015, pp 44 -53

[8] Herry Oktadinata.,Adi Ganda Putra., Microstructure and Hardness Profile of Dissimilar Lap Joint of Type 304 Stainless Steel to SS400 Carbon Steel., Metal Indonesia., JMI Vol 41.,No.2.,Desember 2019

[9] P.Cico., D.Kalincova., M.Kotus., Influence of Welding Method on Microstructural Creation of Welded Joints., Res.Agr.Eng., Vol.57, 2011 (Special Issue) : S50 - S56 